\title{
Equity Begins at the Top: A Modest Proposal
}

\section{Michael Wesley Suman}

You have no doubt heard that meritocracy is a myth. It is one of those old classical liberal ideas that must be discarded in our long march towards achieving “social justice." Towards this end, several years ago, at faculty leader training sessions initiated by then President of the University of California Janet Napolitano, attendees were instructed not to utter such repression-friendly microaggressions as "America is the land of opportunity" and "I believe the most qualified person should get the job." ${ }^{1}$ These shibboleths were to be avoided as nothing less than tools of oppression, used by elites to justify and defend their position of undeserved privilege and to trick the marginalized into believing that lack of achievement is their fault.

To dismantle the oppressive meritocracy and defeat the myth, so-called "merit-based" elite high schools have been under attack as of late. In the fall of 2020, the Fairfax County Public School Board in Virginia eliminated the entrance test for the prestigious Thomas Jefferson High School for Science and Technology. Similarly, the San Francisco Board of Education voted in February 2021 to abandon the merit-based admissions process at highly regarded Lowell High School, after students, faculty, and others linked the system to the perpetuation of white supremacy. At Lowell students will now be chosen by lottery. New York Mayor Bill de Blasio has long advocated similar plans to end merit-based admissions at his city's elite public schools, basically replacing them with the drawing of lots, advancing an underlying goal to "redistribute wealth." 2

Musing about the myth of meritocracy at the service of oppression, white supremacy, and all else that is rotten within "late-stage" capitalism in Amerika, I have recently found myself asking, "Who are the most privileged people I

\footnotetext{
1 "Tool: Recognizing Microaggressions and the Messages They Send," https://www.up.edu/inclusion/ files/2.-dws---handout-for-recognizing-microaggressions-and-the-messages-they-send.pdf.

2 Bill de Blasio, press conference, December 18, 2020, https://ground.news/article/1275bd6b-2f31-4cec$8 f c c-4 a 858 c 9150 e 4$.
} 
know?" Although cutting too close to home-I have been a lecturer at UCLA for over a quarter century-I had to answer that it is probably university faculty members. Who is more pampered and spoiled? Good hours (and rather few of them in the classroom). Decent pay. Job protection for those who advance. No heavy lifting. One of the few groups to still have defined pension plans. Who has taken greater advantage of the oppressive system to feather their nests at the expense of others than university faculty? And what do they give back in return?

A few months ago, I was re-reading Thomas Sowell's old collection Barbarians Inside the Gates and Other Controversial Essays (1999). In the essay “Behind 'Publish or Perish" Sowell noted that, "It is hard to imagine how the world would be any worse off, on net balance, if the entire output of the sociology profession over the past fifty years had never been published."3 Again, this cuts too close to home as I am a sociologist, but I had to admit to myself, "By Jove, he's right!" His point still rings true today more than twenty years after it was written.

All this got me to thinking, putting two and two together. What is the best way to level the playing field, redistribute the wealth, strike a blow for social justice, and end this sham meritocracy? Inspired by Elizabeth Warren, I told myself to "think big!" So, why not start at the top? Why not go after the elite of the elites, the most privileged people I know, all those university faculty members, especially those at our top universities? Those in the social sciences and humanities, whose production re Sowell's contention is most suspect, seem especially ripe targets. After all, they are the ones who have proposed this leveling strategy in the first place. Surely, they will be willing to be the first in line. Out with them in the name of social justice!

Let's start our destruction of the oppressive, corrupt meritocracy with a thorough cleaning of the Augean stables of academia. And we could replace these privileged elites through lotteries of interested parties from the general population, drawing from a truly diverse, inclusive, and equitable random sample! After all, what is good for the goose is good for the gander.

3 Thomas Sowell, Barbarians Inside the Gates and Other Controversial Essays, (Hoover Institution Press, 1999), 212. 